\title{
The Impact of the 2007 Global Financial Crisis on IPO Performance in Asian-Pacific Emerging Markets
}

\author{
George Giannopoulos ${ }^{1 *}$, Stavros Degiannakis ${ }^{2}$, Andrew Holt ${ }^{3}$, Teerapon Pongpoonsuksri ${ }^{1}$ \\ ${ }^{1}$ Kingston Business School, Kingston University, London, UK \\ ${ }^{2}$ Department of Economic and Regional Development, Panteion University of Social and Political Sciences, Athens, Greece \\ ${ }^{3}$ Department of Accounting, Metropolitan State University of Denver, Denver, USA \\ Email: *g.giannopoulos@kingston.ac.uk
}

How to cite this paper: Giannopoulos, G., Degiannakis, S., Holt, A. and Pongpoonsuksri, T. (2018) The Impact of the 2007 Global Financial Crisis on IPO Performance in Asian-Pacific Emerging Markets. Theoretical Economics Letters, 8, 2640-2672. https://doi.org/10.4236/tel.2018.811168

Received: July 10, 2018

Accepted: August 27, 2018

Published: August 30, 2018

Copyright $\odot 2018$ by authors and Scientific Research Publishing Inc. This work is licensed under the Creative Commons Attribution International License (CC BY 4.0).

http://creativecommons.org/licenses/by/4.0/

\begin{abstract}
This paper assesses the comparative impact of the 2007 global financial crisis on the short and long-term performance of initial public offerings (IPOs) in the Asian-Pacific emerging markets of Thailand, China, South Korea, and Malaysia. Our results indicate that the short-term performance or underpricing of Thai IPOs increased from $19 \%$ to $44 \%$ between the pre-crisis and post-crisis periods. IPOs in each of the three other emerging markets experienced a reduction in underpricing after the financial crisis. While our results are consistent with previous IPO research, the degree of underpricing in each emerging market exceeded the levels found in studies of IPOs in developed countries. In terms of the long-term performance of IPOs, our results suggest that IPOs in Thailand, China, and South Korea performed better in the post-crisis period, while Malaysian IPOs performed worse. Our overall findings suggest that the 2007 financial crisis affected IPO performance and economic growth in each of the markets studied.
\end{abstract}

\section{Keywords}

Benchmark-Adjusted Returns, Emerging Markets, Financial Crisis, IPO, Performance, Underpricing

\section{Introduction}

An initial public offering (IPO) is a process by which a private company makes its first sale of shares to the general public with the assistance of an investment bank. An issuer sells its shares to an investment bank (the "underwriter") who then re-sells the issuer's shares to the public, via a stock exchange. IPO offerings 
are often underpriced since a share's offer price (the price offered to the company by the underwriter) is likely to be lower than its closing price on the first day of trading. If the difference between these two price points is multiplied by the number of shares sold the resulting amount equals the money "left on the table" by the issuing company. During the 1990s, U.S IPO issuers paid $\$ 13$ billion in fees to underwriters but left more than $\$ 27$ billion on the table [1]. As a result, many studies have focused on investigating the short-term (underpricing) and long-term performance of IPOs [2] [3] [4]. Other work has focused on fluctuations within the total volume of IPOs in relation to aggregate capital demands of private companies [5] and the valuation of IPOs using comparable firm multiples [6].

Despite this previous work, Yong [7] identifies that relatively little is known about IPO activity in certain Asian markets. Recent research suggests that the Asia-Pacific region leads world markets in terms of the growth and support of IPOs. During 2012, the Asia-Pacific region accounted for 57\% and $44 \%$ of total worldwide IPOs and total global capital raised from IPOs. More specifically, the largest IPO in 2012, apart from that of Facebook, was undertaken by the Malaysian firm, Felda. Within the Asian-Pacific region, the majority of IPO activity is conducted in China, Japan, Malaysia, Singapore, South Korea, and Thailand. Of these, Thailand, China, South Korea, and Malaysia are classified as emerging markets. Despite the relative importance of IPOs in these emerging markets, few studies have investigating IPO activity in the region. As a result, the present study focuses on IPO activity in four specific Asian-Pacific emerging markets: Thailand, China, South Korea, and Malaysia. The paper does this by providing a comparative assessment as to how the 2007 global financial crisis affected IPO activity in each country by investigating the relative short and long-term performance of IPOs in each market during the five years immediately before, and after the 2007 global financial crisis.

Event study methodology is used to evaluate the short-term and long-term performance of IPOs in each country using 1 day and 36 month event windows, respectively. Short-term performance is measured using the market-adjusted abnormal return, and long-term performance is calculated using the cumulative average market-adjusted return. The total numbers of observations in each country ranged from 220 to 1,300 observations and include ten years of IPO data that cover the period from $1^{\text {st }}$ January 2003 to $31^{\text {st }}$ December 2012.

The results of this study suggest that the short-term performance or underpricing of Thai IPOs increased from $19 \%$ to $44 \%$ between the pre-crisis and post-crisis periods. In contrast, each of the three other emerging markets studied experienced a reduction in IPO underpricing after the financial crisis. In China, underpricing decreased from $114 \%$ to $41.5 \%$, in South Korea it declined from $43.7 \%$ to $27.9 \%$, and in Malaysia it fell from $30.1 \%$ to $11.3 \%$.

In terms of the long-term performance of IPOs, the results of this study suggest that in Thailand, China, and South Korea, IPOs performed better in the post-crisis period, while Malaysian IPOs performed worse. The 36 months CARs 
for IPOs in each country during the pre-crisis and post crisis periods were: Thailand $7.5 \%$ and $43.1 \%$, China 5\% and 25\%, South Korea $18.9 \%$ and 50.5\%, and Malaysia $-25.8 \%$ and $-30.9 \%$.

The rest of this study is structured as follows: section two critically evaluates the theoretical framework of short-term performance (underpicing) and long-term performance of IPOs. In addition it presents the empirical evidence of short-term and long-term performance of IPOs in each of the four emerging Asian-pacific countries. Section three discusses the sample data selection procedure and the methodology used to investigate this study's research objectives. Section four presents the research findings and a final section concludes this paper.

\section{Literature Review}

This section critically evaluates the existing theoretical and empirical literature on IPOs with a specific focus on the issues of short-term (underpricing) and long-term performance of IPOs.

\subsection{Theoretical Framework}

The "abnormal" positive return achieved during the first trading day of an IPO has been an intriguing phenomenon for decades. Ljungqvist [8] defines underpricing as "the percentage difference between the price at which the IPO shares were sold to investors (the offer price) and the price at which the shares subsequently trade in the market". Since the 1970s, there has been a great deal of research dedicated to explaining and providing possible reasons as to why new issuances of equity are usually under-priced [9] [10].

There are many theoretical paths in the relevant literature trying to interpret IPOs underpricing. Information asymmetry between the market participants in IPOS is a key element for the majority of the different theoretical explanations offered.

More recently, Rock [11] provides a model that explains the underpricing phenomena of IPOs by suggesting that there is asymmetric information among investors, with certain parties holding superior information that could signal to other uninformed investors about whether an IPO is a good or bad investment. As a result, the underwriter must price the shares at a discount to attract the uninformed investors [11].

\subsubsection{Asymmetric Information Theory}

When a firm goes public, there are normally three main participants in this process: the issuing firm, the underwriter (investment bank), and the investors. In an asymmetric information model, it is believed that information is not equally shared among the three participating groups. In other words, certain parties have more information than the others. Under this theoretical model, investors are classified into two groups: informed and uninformed investors. Rock [11] suggests that informed investors (parties holding superior informa- 
tion) could signal to other uninformed investors about whether an IPO is a good or bad investment. As a result, the underwriter must price the shares at a discount to attract the uninformed investors.

In a model devised by Baron [12], when a firm issues an IPO it hires an investment bank to perform three functions: underwriting, advising, and distribution of the IPOs. An important assumption of this model is that the investment bank has superior knowledge of the capital market than the firm itself. A firm that has uncertainty and less information about the market demand for its IPO would be more willing to accept a lower offer price for its stock. As a result, the greater the level of underpricing, the investment bank has more incentive to perform better in selling the IPO.

\subsubsection{Underwriter Reputation Theory}

This theory suggests that underpricing can be partly explained by reputation of the underwriting institution. As underpricing is affecting "ex-ante" uncertainty, issuing firms aim to hire reputable underwriters. Beatty and Ritter [3] suggest that there is a positive relationship between the ex-ante uncertainty about an IPO's value and the eventual underpricing of that IPO. They also argue that an investment banker is the main enforcer of underpricing. While an investment banker may not be able to perfectly forecast the value of the issuing firms, bankers who price the shares "off the line" (too high or too low) will be punished by the market, so that those investment bankers lose market share in subsequent periods.

Nevertheless, the underwriter reputation theory is challenged by the inconsistency of its predictions. For example, Cooney, et al. [13] discovered a reverse relationship between underwriter reputation and the degree of underpricing in work conducted on a sample of IPOs during the period 1981-1998. Their results indicated a negative relationship between the reputation of underwriters and underpricing during the 1980s, but the relationship was found to be positive in IPOs completed during the 1990s. Despite these results, Cooney, et al. [13] suggest that underwriter reputation theory is still valid if one applies certain classifications to screen samples.

\subsubsection{Owner Dispersion Theory}

This theory suggests that owners of issuing firms ensure that IPOs are oversubscribed [14]. If investor demand is more than the supply of shares available, the shares will be rationed to investors. By using underpricing to create a surplus in demand, the issuer can control the allocation of post-IPO ownership strategically through the share allocation process in order to retain control after the IPO takes place.

Booth, et al. [15] argue that the issuers demand both a preferable ownership structure and liquidity in the secondary market for the shares issued. Such demands create an incentive for issuers to underprice IPOs, as promoting oversubscription helps the issuer to increase the liquidity of their shares in the sec- 
ondary market because if the firm's shares are held by a broad group of investors they will have higher liquidity.

\subsubsection{Lawsuit Avoidance Theory}

In the United States of America (USA), the Securities Act of 1933 requires that all signatories to a prospectus are liable for any material omissions within it. As a result, Tinic, et al. [16] develops the hypothesis that underpricing is a form of insurance against the potential legal liability and associated damages to the reputation of both investment bankers and the issuers. In other words, underpricing implicitly reduces the maximum dollar amount liability of possible lawsuits, since the damages are limited to the offer price.

However, the lawsuit avoidance theory is criticised by other authors. Drake, et al. [17] investigated 93 IPOs that involved lawsuits after each public offering took place and found that the sued firms had similar underpricing levels to those firms that did not subsequently get sued. This result of this and other studies suggest that lawsuits have little influence on the degree of IPO underpricing [18].

\subsubsection{Tax Motive Theory}

Dandapani, et al. [19] suggest that there is a relationship between the amount of personal tax paid by entrepreneurs on an IPO and its level of underpricing. The presence of taxes reinforces underpricing in IPOs. There are two main assumptions within this theoretical model. Firstly, an entrepreneur is a person who is responsible for setting the issue price of the shares and may retain some portion of ownership. Second, the purpose behind the IPO is to fund a project with a positive net present value (NPV). Normally, the value of a firm will increase when a new project with a positive NPV is undertaken. As a result, the entrepreneur might choose to withdraw this increase in corporate value in a form of a royalty or dividend. However, if the shares of an IPO are underpriced and the entrepreneur retains some portion of the shares, the entrepreneur can keep the gain in a form of unrealised capital gain. Since an unrealised gain is not immediately taxable, the entrepreneur may prefer to convert it to a realised taxable gain either in the form of a dividend or royalty, depending on the favourable tax rates payable by the entrepreneur. A variation of this theory was provided by Rydqvist [20], who suggests that underpricing is likely to be influenced by the prevailing tax treatment of ordinary income versus capital gains.

\subsubsection{Psychological Bias Theory}

In general, IPOs are most likely to be underpriced in order to provide investors with initial returns in excess of market norms. However, the long-term performance of IPOs is often inferior to the corresponding market-index benchmark of performance [21]. As a result, certain authors argue that underwriters actually set the offer price equal to the true value of the firm, but the initial excess return is influenced by an overreaction by irrational investors.

For example, Daniel, et al. [22] utilise a psychological bias perspective to sug- 
gest that certain investors are overconfident about the correctness of their private information about an IPO. As a result, they trust their own private information rather than publicly available information or signals from the company itself. This behaviour leads to overestimation in the performance of IPOs and overreaction on the first trading day. Furthermore, investors tend to persistently ignore the subsequent public information about the IPO, making the overreaction in the share price persist longer. Similarly, Bloomfield, et al. [23] found that investors tend to overreact to unreliable information and underreact to reliable information. However, in the long-term, stock prices tend to reflect the correct value of the firm and the majority of IPOs provide poor long-term performance [21].

\subsubsection{Fads Theory}

Shiller, et al. [24] developed the "Fads" theory to suggest that investment is another activity where investors spend time discussing, reading, and gossiping about successful or failed investments. As a result, it is likely that investor behaviour may be influenced by social dynamics. This view is supported by a number of authors, and suggests that social movements, fashions, or fads are an important cause of speculation in asset price movements.

Aggarwal, et al. [25] tested the existence of "fads" within the market for IPOs by developed a model that provided two possible explanations for underpricing in IPOs. The first explanation was that investment banks systematically underprice IPOs to be lower than their intrinsic value. The second explanation was that the stock prices of IPOs in early aftermarket trading are subject to overvaluation or fads. The results provided by Aggarwal, et al. [25] suggest that investors made gains from early price appreciation and losses in subsequent price declines. These results challenge the efficient market hypothesis [26] and demonstrate that stock markets might be inefficient, otherwise, the returns in early aftermarket should be close to index returns. Despite this supporting evidence, the theory of fads with the pricing of IPOs is questioned by many researchers such as Kleidon [27], Marsh and Merton [28], and Lee, et al. [29].

\subsection{Empirical Evidence of Short-Term Performance (Underpricing) of IPOs}

The performance of IPOs has been widely investigated by many researchers since the 1970s. Underpricing of IPOs has been highlighted by researchers and the evidence gathered to support its existence is compelling. McDonald, et al. [30] examined the behaviour of 142 IPOs in the US market (Dow Jones) during the period 1969-70 and found that on average the return on an IPO in the first week after trading was $28.5 \%$. Ibbotson [9] found an initial average return of $11.4 \%$ on IPOs offered during the 1960s, and Ibbotson, et al. [2] reported a $16.8 \%$ excess return on IPOs during their first month of trading when compared to the performance benchmark provided by Standard and Poor 500 Index. Finally, Ritter [31] in an analysis of more than 5000 IPOs during the period 
1960-1982, found a positive yield that averaged $18.8 \%$.

Evidence of IPO underpricing has also been discovered in other established economies throughout the world. Jog, et al. [32] and Kooli, et al. [33] found underpricing of IPOs in the Canadian market. Ljungqvist [34] discovered underpricing of IPOs in Germany. While in Asia, Dawson [35] found IPO underpricing in three Asian stock markets; Hong Kong, Singapore, and Malaysia. Mok, et al. [36], Su, et al. [37] [38], and Chan, et al. [39] found evidence of IPO underpricing in China, and Perera, et al. [40] discovered evidence of short-term underpricing in Australian IPOs. In the UK, Boulton, et al. [41] recorded an average level of $17.7 \%$ underpricing in UK IPOs completed during the period from 2000 to 2006. Additionally, Boulton, et al. [41] found that those countries whose public firms produce higher quality earning information tend to have lower levels of IPO underpricing.

Although there is considerable evidence suggesting that IPOs on average are underpriced and therefore result in unusual initial returns mainly due to information asymmetry [42] [43] [44] [45], a large proportion of IPOs experience an eventual decline in price in the long-run. Instead of underpricing, Purnanandam, et al. [21] argue that IPOs are actually overpriced, as they provide a high first-day return but then generate poor performance in the long-run.

\subsection{Long-Term Performance of IPOs}

Unlike the consistent outstanding first-day return, IPOs appear to provide poor levels of long-term performance. In the US, Ritter [46] identifies that IPOs generally underperform the market or public companies with similar characteristics, such as size and industry. To test the long-term performance of IPOs, Ritter [46] analysed 1500 IPOs during the period 1975 to 1984 by comparing their return with the return of benchmark companies. Ritter [46] established that the IPOs significantly underperformed the benchmark by almost 30\% after a 36 month period. Similarly, Ibbotson [9] examined and computed the excess returns on IPOs for a 10-year period from 1960 to 1969, and found that returns were no different from the market return. However, Ibbotson [9] did find positive performance during the first year of IPO trading, negative performance during both the second to fourth years, and positive performance during the fifth year of trading.

Generally IPOs in many world markets underperform in the long-term when compared to benchmarks such as the corresponding market index return or performance of comparable firms. For example, Lee, etc [29] found poor long-term performance amongst Australian IPOs. Ljungqvist [34] found that after 3-years German IPOs underperformed Germany's broad market index by 12\%. Jaskiewicz, et al. [47] examined IPOs in Spain during 1990-2000 and found that, on average, Spanish IPOs generated a $36.7 \%$ lower return than the market index.

Although the long-term performance of IPOs may be affected by many fac- 
tors, one important factor appears to be the reputation of the underwriting institution. Carter, et al. [48] suggest that IPO stocks handled by reputable underwriters tend to experience less severe underperformance relative to the market. $\mathrm{Su}$, et al. [49] also investigated the impact of underwriter reputation on the long-term performance of 590 Chinese IPOs during 2001-2008. They found that the long-term performance had a positive relationship with underwriter reputation. Their results suggest that IPOs issued by prestigious underwriters tend to perform better in the long-run than IPOs issued by general underwriters. Similarly, Dong, et al. [50] found that quality of the underwriter influences the long-term performance of IPOs. IPO firms with higher quality underwriters significantly outperform IPO with lower quality underwriters. Finally, Ritter [46] suggests that the long-term performance (underperformance) of IPOs may vary across industries.

\subsection{IPOs in Emerging Markets}

Emerging markets are becoming more important in terms of the global IPO market. Davies [51] reports that even the London Stock Exchange, one of the most developed capital markets, is not one of the top five IPO markets in terms of total value of IPOs offered. Similarly, Chinese IPO markets, including mainland China, Hong Kong, and Taiwan, dominated the global IPO market during the first 11 months of deals during 2012.

IPO markets in emerging economies appear to be significantly different from other, more established IPO markets. For example, Bekaert [52] suggests that there are investment barriers associated with emerging equity markets in nineteen different countries. These emerging countries tend to have poor credit ratings, high and volatile levels of inflation, lack high-quality regulatory and accounting frameworks, and have limitations in terms of total market size.

Even though the systematic risk of emerging markets differs from that exhibited by developed markets, IPO underpricing is still likely to be found [53]. An emerging market, however, may have specific characteristics, such as country risk, economic conditions, and regulations that may influence both the underpricing and long-term performance of IPOs. The next section of this paper briefly discusses the characteristics of the IPO markets in the Asian-Pacific emerging markets of China, South Korea, Malaysia, and Thailand.

\subsubsection{IPOs in China}

China has two main stock exchanges, Shanghai and Shenzhen, which operate separately and independently from each other. The Shanghai Stock Exchange was established in 1990 and in the following year Shenzhen was founded. Since then, Chinese stock markets have experienced rapid development and high growth rates. From 1992 to 2000, the number of companies listed on Chinese markets increased from 53 to 1088 companies. Between 2007 and 2012, the Chinese economy grew by nearly 60 percent, and in 2000, Chinese stock markets (in aggregate) were ranked in $10^{\text {th }}$ place in terms of total worldwide market capitali- 
zation, and accounted for $1.81 \%$ of the total global market capitalisation. In 2012, Chinese stock markets ranked in the $2^{\text {nd }}$ place and accounted for $6.95 \%$ of the world market capitalization.

Since China is one of the fastest growing economies in the world, researchers have provided a wealth of information about Chinese stock markets including the domestic IPO market. Research focused on the short-term performance (underpricing) and long-term performance of IPOs in China during the period 1990-1993. Mok, et al. [36] found extreme underpricing of 289\% in A-share IPOs while B-Share ${ }^{1}$ IPOs were underpriced by $26 \%$. This high level of underpricing appears to be a feature of Chinese IPO markets, as Chan, et al. [39] also found A-Share and B-Share underpricing of $178 \%$ and $11.6 \%$, respectively in their study of IPOs issued in China during the period 1993-1998.

$\mathrm{Su}$, et al. [38] suggest that the long time period between the date of the offer and the first trading day is linked to a degree in the underpricing in Chinese IPO markets. Su, et al. [37] also suggest IPO in China may be the result of signalling, and that IPO firms in China may recoup the cost of underpricing from subsequent share issues.

\subsubsection{IPOs in South Korea}

South Korea has one security exchange located in Busan. The exchange is known as the Korea Exchange (KRX) and has integrated various types of trading such as stocks, bonds, futures, and other derivatives. There are three markets operating under the umbrella of the KRX. The Korea Composite Stock Price Index (KOSPI) is the main board listing medium to large capital stocks. The second market is the Korea Securities Dealers Association Automated Quotation (KOSDAQ) which is where small and medium companies with growth potential are listed. The third and final market is the Korea New Exchange (KONEX), which is relatively new, and provides finance for small business ventures looking to raise capital. Each market has its own specifications and requirements. For instance, the KOSPI and KOSDAQ are different in terms of the size of each company's capital requirements but also in terms of their qualitative requirements, such as the listing requirements and fees.

Empirical evidence has shown that when firms go public, a significant degree of underpricing can be found in IPOs within many markets. The Korean IPO market is no exception, as during the period 2000-2007 the average initial return of IPOs was $57.6 \%$ which was considerably higher than the $25.7 \%$ achieved by IPOs in the US market during the same period. Many researchers have attempted to explain the issue of underpricing within Korean markets since the

\footnotetext{
1"The two types of tradeable stocks on the two exchanges in China are personal ' $\mathrm{A}$ ' shares and ' $\mathrm{B}$ ' shares. The personal ' $A$ ' shares, issued by IPO and traded in domestic currency, are exclusively for domestic Chinese investors. The B shares, introduced in Shanghai in February 1992 and allocated primarily by private placements, are traded in US currency and are exclusively for foreign investors. These ' $\mathrm{B}$ ' shares, designed to attract much-needed foreign capital and to transform the management of the enterprises, are held mainly by foreign institutional investors. The A-and B-share markets are segmented given their ownership and institutional differences" [36].
} 
early 1990s. Kim, et al. [54] explored the motives for going public and underpricing and identified that the motive behind the IPO issue was related to level of underpricing. These results suggest that when firms issue IPOs as their last resort of financing, the degree of underpricing is significantly higher than when firms use IPOs to diversify ownership. Furthermore, Kim, et al. [55] suggest that financial variables such as earning per share (EPS), offer size, type of industry, and offer type may also have a significant effect on IPO prices in South Korea.

\subsubsection{IPOs in Malaysia}

The exchange in Malaysia is known as the Bursa Malaysia, which provides a fully-integrated exchange which consists of several wholly-owned subsidiaries. Each subsidiary provides and operates exchange-related services for different type of financial securities (e.g. equities, bonds, derivatives). In Malaysia, there are two separate markets, the Main market and the ACE market. Generally, the Main market provides a platform for well-established companies to raise funds while the ACE market provides alternative source of funds for companies with growth potential. In 2012, Bursa Malaysia was ranked $21^{\text {st }}$ in terms of global market capitalisation with a total of 921 listed companies.

The Malaysian IPO market has a unique way of defining an IPO issue. IPOs in Malaysia may refer to public offers by private sector companies or can be privatisation initial public offers (PIPOs) issued by state-owned companies [56]. Malaysia has promoted privatisation since 1984. Researchers have found differences in the degree of underpricing between private sector IPOs and PIPOs in most markets. For instance, Menyah, et al. [57] found that PIPOs in the UK market were on average underpriced by $38.7 \%$, while IPOs were underpriced by only 3.48\%. Menyah, et al. [58] examined the Malaysian market during the period 1984-1995 and discovered similar patterns but with a higher magnitude of underpricing. IPOs in the Malaysian market had an average initial excess return of $52.5 \%$, whereas the average achieved by PIPOs was $103.5 \%$.

These results suggest that IPOs in emerging markets appear to have comparatively greater levels of underpricing than those offered in developed markets. However, the long-term performance of Malaysian IPOs appears to contradict the general findings from US studies of IPOs, which suggest a poor long-term performance in IPOs. For example, Jelic, et al. [59] examined IPOs in Malaysia during the period 1980-1995 and found positive levels of long-term performance in these IPOs for up to 3 years.

\subsubsection{IPOs in Thailand}

The Stock Exchange of Thailand (SET) is a juristic entity established in 1974 and serves as a platform for the trading of listed securities. In 2012, SET had over 600 companies listed with an aggregate market capitalization of \$383 Billion, making it the $24^{\text {th }}$ ranked global financial market. Thailand also has a Market for Alternative Investment (MAI) where small and medium size companies seeking funds are listed. In terms of prior work on the IPO market in Thailand, Chorruk, et al. 
[60] identified differences in the degree of underpricing in Thailand in the periods before and after the 1997 financial crisis. During the pre-crisis period 1988-1989, underpricing was 56.73\% [61] and during 1985-1992 it was measured at $63.49 \%$ [62].

Chorruk, et al. [60] examined the short-term performance of IPOs in Thailand in the period after the Asian financial crisis, and identified that the degree of underpricing in Thailand was significantly lower. Their results found that IPOs in Thailand are on average underpriced by only $17.6 \%$ which is lower than most developed markets. In contrast, the long-term performance of IPOs in Thailand appears to be poor. Chorruk, et al. [60] studied the cumulative monthly performances of Thai IPOs between their 1st and 36th month of trading. They found that after 24 months of outperforming the market, Thai IPOs underperformed the market. Vithessonthi [63] provides additional evidence about this by suggesting that in the long-term Thai IPOs underperformed comparable firms by $41.68 \%$, which is a substantially greater level of underperformance than IPOs in the developed markets. However, Allen, et al. [62] present contrasting evidence showing that the long-term performance of Thai IPOs outperformed the market returns by $10.02 \%$.

While the above work provides us with a good understanding of the IPO market in Thailand before the 2007 financial crisis, at the same time it appears appropriate to develop Chorruk's, et al. [60] work in order to investigate the impact of the 2007 financial crisis on the Thai IPO market.

\subsection{Summarizing the Existing Work on IPOs in Emerging (Asian-Pacific) Markets}

The literature review, on IPOs suggests underpricing (in the short-term) and poor long-term performance. Empirical evidence of IPO underpricing has been discovered in most countries where equity markets are available. However, there are differences in the extent of this underpricing, with differences between countries, industries, and or sectors. IPOs in emerging (Asian-Pacific) markets tend to provide investors with higher initial returns than IPOs issued in developed market. As a result, companies in emerging markets appear to bear a higher cost from issuing IPOs, and as a result, more money is expected to be left on the table. There many reasons that may explain this underpricing, these include asymmetric information theory, agency theory, signalling theory and other similar theories. Despite this, the exact cause of underpricing is still intensely debated among researchers and there is no definitive conclusion on the matter.

In terms of long-term performance of IPOs, the literature provides evidence that suggests that IPOs are most likely to perform poorly in the long-run. Yet, some outliers have been found in emerging markets, such as Korean IPOs and Thai IPOs, where long-term performance can outrun benchmarks. Some researchers suggest that the poor long-term performance is caused by investors being too optimistic about the potential growth of young firms [46] or that IPOs may be overpriced from the very start [21]. 


\section{Methodology}

The section explains the methodology used to evaluate the short-term and long-term stock price performance of IPOs in Thailand, China, South Korea and Malaysia during the period before and after the 2007 financial crisis.

\subsection{Data}

IPO data are extracted from Bloomberg for a period of 10 years starting from $1^{\text {st }}$ of January 2003 to $31^{\text {st }}$ December $2012^{2}$. The sample was divided into two sub-periods which are5 years ( $1^{\text {st }}$ January 2003-31 ${ }^{\text {st }}$ December 2007) before and 5 years ( $1^{\text {st }}$ January $2008-31^{\text {st }}$ December 2012) after the global financial crisis ${ }^{3}$. The total number of useable observations for Thailand, China, South Korea and Malaysia are 220, 1299, 643, and 332, respectively. In addition, the Bloomberg database is used to provide the daily and monthly historical closing prices of IPO firms and the relevant market index for each country.

\subsection{Research Method}

McWilliams, et al. [64] and MacKinlay [65] indicate that an event study is the appropriate mean to assess the impact of an unexpected event. Furthermore, McWilliams, et al. [64] suggest that this research approach can also be used to determine whether there is an abnormal stock price effect connected with this unanticipated event. In addition to these strengths of an event study methodology, it also avoids the need to utilise accounting-based measures of profit, which may be manipulated by insiders.

As a result, an event study methodology appears to be a suitable choice of method for investigating the impact of the 2007 global financial crisis on the short-term and long-term performance of IPOs. However, there are crucial assumptions associated with the event study approach. These include the following assumptions: 1) markets are efficient, 2) the event is not anticipated, and 3) there were no confounding effects during the event window.

The primary task for conducting an event study is to define the period in which the impact of the event is going to be measured. In this study, the event windows used to measure the short-term and long-term performance of IPOs are 1 day and 36 months, respectively.

\subsection{The Measurement of Short-Term Performance and Underpricing}

According to Rosa, et al. [66] and Chi, et al. [67], the short-term performance of

${ }^{2}$ The sample period 2003-2012 is chosen due to data constraints i.e. the investigation of the long-term IPO performance requires stock market data up to 36 months after the IPO announcement.

${ }^{3}$ We divided the sample period into two sub-periods because we aim to capture the impact of financial crisis on the IPO performance therefore we document the IPO performance before and after the 2007 financial crisis and aim to identify whether this performance is significant different between the two sub-periods. 
IPOs can be measured using the percentage increase of the closing price on the first trading day over the original issue price:

$$
R_{i_{1}}=\left(\frac{P_{c, i}}{P_{\text {issue }}}\right)-1,
$$

where $P_{c, i}$ is the closing price on the first trading day of an $\mathrm{IPO}_{i}$ and $P_{\text {issue }}$ is the issue price of $\mathrm{IPO}_{i}$. The corresponding benchmark of each country is its stock market index. The return on the market index in a corresponding period is:

$$
R_{m_{1}}=\left(\frac{P_{m_{1}}}{P_{m_{\text {issue }}}}\right)-1,
$$

where $R_{m_{1}}$ is the first day's comparable market return, $R_{m_{1}}$ is the closing market index value on the first trading day and $P_{m_{\text {issue }}}$ is the closing market index value on the offering day of the corresponding stock.

The market-adjusted abnormal return for $\mathrm{IPO}_{i}$ can be calculated by using the two returns calculated in Equation (1) and Equation (2) as follows:

$$
M A A R_{i_{1}}=R_{i_{1}}-R_{m_{1}} .
$$

The sample mean of market-adjusted abnormal return for the first day of trading can be calculated as:

$$
\overline{M A A R}_{1}=\frac{1}{n} \sum_{i=1}^{n} M A A R_{i_{1}} .
$$

To test whether the mean of market-adjusted return is significantly different from zero, standardised $t$-statistic is computed as:

$$
t_{M A A R}=\frac{\overline{M A A R}_{1}}{S / \sqrt{n}},
$$

where $S$ is the sample standard deviation of abnormal returns $\left(M A A R_{i_{1}}\right)$ and $n$ is the number of sample IPOs. Additionally, another measurement tool applied is the wealth relative, $\mathrm{WR}_{1}$, which can be calculated as:

$$
\mathrm{WR}_{1}=\frac{1+\frac{1}{n} \sum_{i=1}^{n} R_{i_{1}}}{1+\frac{1}{n} \sum_{m=1}^{n} R_{m_{1}}} .
$$

According to Ritter [46], a wealth relative of greater than 1.00 indicates that IPOs outperform the market in the corresponding period. A wealth relative of less than 1.00 indicates that IPOs underperform the market.

\subsection{The Measurement of Long-Term Performance-The Aftermarket Performance}

Cumulative abnormal return (CARs)

Cumulative abnormal returns (CARs) were first used by Ritter [46] to measure the long-term performance of IPOs. In order to calculate CARs, first the raw 
return of the $\mathrm{IPO}_{i}$ for the event month $t$ is computed as:

$$
R_{i, t}=\left(\frac{P_{i, t}}{P_{i, t-1}}\right)-1,
$$

where $R_{i, t}$ is the monthly raw return of the $\mathrm{IPO}_{i}$ in the event month $t, P_{i, t}$ is the closing price at the end of month $t$ of the $\mathrm{IPO}_{p}, P_{i, t-1}$ is the closing price of the $\mathrm{IPO}_{i}$ at the end of month $t-1^{4}$. Second, the same mathematical rational is applied to calculate the benchmark return for the $\mathrm{IPO}_{i}$ as follows:

$$
R_{m, t}=\left(\frac{P_{m, t}}{P_{m . t-1}}\right)-1,
$$

where $R_{m, t}$ is the monthly benchmark return of the $\mathrm{IPO}_{i}$ in the event month $t$, $P_{m, t}$ is the closing price of the benchmark at the end of month $t$ of the IPO, $P_{m . t-1}$ is the closing price of the benchmark at the end of month $t-1$.

Third, the benchmark (market) adjusted abnormal returns $A R_{i, t}$ are computed by taking the difference of the raw return $R_{i, t}$ of the $\mathrm{IPO}_{i}$ and the benchmark return $R_{m, t}$ over the corresponding period (event month $t$ ).

$$
A R_{i, t}=R_{i, t}-R_{m, t} \text {. }
$$

Fourth, the average abnormal benchmark-adjusted return of the portfolio with $n$ IPOs for the event month $t$ is calculated as follows:

$$
\overline{A R_{t}}=\frac{1}{n} \sum_{i=1}^{n} A R_{i, t}
$$

Fifth, in order to measure the cumulative average benchmark-adjusted returns for the long-term performance from event month 1 to month $t$, the following calculation is applied:

$$
\overline{C A R_{1, t}}=\sum_{t=1}^{t} \overline{A R_{t}} .
$$

Finally, the standardised $t$-statistic is computed to assess whether the cumulative average benchmark-adjusted returns is significantly different from zero.

$$
t_{C A R}=\frac{\overline{C A R_{1, t}}}{S / \sqrt{n}} .
$$

The above measurements of long-term performance of IPOs are widely accepted in the literature [46] [68].

\subsection{Performance Benchmarks}

As discussed earlier, three of the Asian-Pacific emerging markets, under consideration, have more than one stock exchange (e.g. Thailand, China, and South Korea). As the IPOs in these countries may be issued on different stock markets, the corresponding benchmark(s) of each IPOs is (are) explained as follows.

For Thailand, two benchmarks are applied in the above calculations. The

${ }^{4} \mathrm{We}$ investigate the long term performance post the listing month, so the 12,24 and 36 months long term IPO returns do not include the listing month return. i.e., we exclude the impact of short term underpricing in the measurement of the long term IPO performance. 
Stock Exchange of Thailand Index is the benchmark for IPOs issued in SET market. The Market for Alternative Investment Index is the benchmark for its corresponding IPOs. For China, the benchmarks utilised are the Shanghai Stock Exchange Composite Index and Shenzhen Stock Exchange Composite Index. For South Korea, the Korea Composite Stock Price Index and Korean Securities Dealers Automated Quotations Index are selected as the benchmarks. For Malaysia, the Kuala Lumpur Composite Index is the benchmark against IPOs issued in the Bursa Malaysia stock market.

The underpricing of each IPO is tested against the market index return of the same period to eliminate the confounding effect. The $t$-test is then used to confirm whether the underpricing is significantly different from zero. In the long-term, the performance of IPOs is accessed by using the cumulative average returns which have been adjusted by the market index returns.

\section{Results}

This section presents the results of the research study for the IPOs in Thailand, China, South Korea, and Malaysia.

\subsection{Descriptive Statistics}

Each set of descriptive statistics are presented in a tabular, panel data format, with Thailand, China, South Korea, and Malaysia being allocated to panels A, B, $\mathrm{C}$ and D, respectively. For the purposes of this event study, each country's sample of IPOs were allocated into either a pre-crisis or a post-crisis time-period covering the years 2003-2007 and 2008-2012, respectively.

\subsubsection{Analysis of IPOs in Thailand}

Panel A of Table 1 illustrates that a greater number of IPOs were issued in Thailand before the financial crisis. The 153 IPOs issued during 2003-2007 were primarily made up of IPOs from the industrial, consumer cyclical, financial, and basic material sectors. However, during the post-crisis period the number of IPOs declined substantially, with the consumer cyclical and industrial sectors leading the way. In the post-crisis period, Thailand's 5-year average GDP growth rate decreased from $5.6 \%$ to $2.9 \%$ after 2007 . In addition, market risk and uncertainty were further increased as a result of political unrest that occurred in the country during 2007. Under this context, the reduction in the total number of Thai IPOs is relatively easy to explain. Similarly, Chorruk, et al. [60] found evidence of fewer IPOs being issued after the 1997 financial crisis. In the period of uncertainty after the financial crisis, Thai firms were less confident in their ability to undertake a successful IPO. Going public incurs a large amount of direct (e.g. underwriter fees) and indirect costs (e.g. underpricing cost). If market and economic risk increases, rational investors will require higher compensation, making it even more costly for firms who decide to go public.

Panel A of Table 2 illustrates that before the financial crisis the 70\% of IPOs were issued by the Stock Exchange of Thailand (SET), which is where companies 
Table 1. Numbers of IPOs by industry. (A) Panel A Thailand; (B) Panel B China; (C) Panel C South Korea; (D) Panel D Malaysia.

(A)

\begin{tabular}{ccccccc}
\hline \multirow{2}{*}{ Industry Sector } & \multicolumn{7}{c}{ Numbers of IPOs } \\
\cline { 2 - 7 } & \multicolumn{2}{c}{ '03-07 } & \multicolumn{2}{c}{ '08 - 12 } & \multicolumn{2}{c}{ Total } \\
\hline Basic Materials & 22 & $14 \%$ & 9 & $13 \%$ & 31 & $14 \%$ \\
Communications & 11 & $7 \%$ & 7 & $10 \%$ & 18 & $8 \%$ \\
Consumer, Cyclical & 27 & $18 \%$ & 18 & $27 \%$ & 45 & $20 \%$ \\
Consumer, Non-cyclical & 13 & $8 \%$ & 9 & $13 \%$ & 22 & $10 \%$ \\
Energy & 5 & $3 \%$ & 1 & $1 \%$ & 6 & $3 \%$ \\
Financial & 22 & $14 \%$ & 5 & $7 \%$ & 27 & $12 \%$ \\
Industrial & 45 & $29 \%$ & 14 & $21 \%$ & 59 & $27 \%$ \\
Technology & 7 & $5 \%$ & 1 & $1 \%$ & 8 & $4 \%$ \\
Utilities & 1 & $1 \%$ & 3 & $4 \%$ & 4 & $2 \%$ \\
Total & 153 & & 67 & & 220 & \\
\hline
\end{tabular}

(B)

\begin{tabular}{|c|c|c|c|c|c|c|}
\hline \multirow{3}{*}{$\begin{array}{l}\text { Industry Sector } \\
\text { Basic Materials }\end{array}$} & \multicolumn{6}{|c|}{ Numbers of IPOs } \\
\hline & \multicolumn{2}{|c|}{ '03-07 } & \multicolumn{2}{|c|}{ '08 - 12} & \multicolumn{2}{|c|}{ Total } \\
\hline & 53 & $15 \%$ & 99 & $10 \%$ & 152 & $12 \%$ \\
\hline Communications & 12 & $3 \%$ & 49 & $5 \%$ & 61 & $5 \%$ \\
\hline Consumer, Cyclical & 57 & $16 \%$ & 125 & $13 \%$ & 182 & $14 \%$ \\
\hline Consumer, Non-cyclical & 55 & $16 \%$ & 142 & $15 \%$ & 197 & $15 \%$ \\
\hline Energy & 10 & $3 \%$ & 22 & $2 \%$ & 32 & $2 \%$ \\
\hline Financial & 18 & $5 \%$ & 17 & $2 \%$ & 35 & $3 \%$ \\
\hline Industrial & 107 & $30 \%$ & 403 & $43 \%$ & 510 & $39 \%$ \\
\hline Technology & 30 & $9 \%$ & 81 & $9 \%$ & 111 & $9 \%$ \\
\hline Utilities & 9 & $3 \%$ & 10 & $1 \%$ & 19 & $1 \%$ \\
\hline Total & 351 & & 948 & & 1,299 & \\
\hline
\end{tabular}

(C)

\begin{tabular}{|c|c|c|c|c|c|c|}
\hline \multirow{3}{*}{$\begin{array}{l}\text { Industry Sector } \\
\text { Basic Materials }\end{array}$} & \multicolumn{6}{|c|}{ Numbers of IPOs } \\
\hline & \multicolumn{2}{|c|}{ '03-07 } & \multicolumn{2}{|c|}{ '08 - 12} & \multicolumn{2}{|c|}{ Total } \\
\hline & 17 & $5 \%$ & 19 & $6 \%$ & 36 & $6 \%$ \\
\hline Communications & 45 & $14 \%$ & 35 & $11 \%$ & 80 & $12 \%$ \\
\hline Consumer, Cyclical & 41 & $12 \%$ & 35 & $11 \%$ & 76 & $12 \%$ \\
\hline Consumer, Non-cyclical & 37 & $11 \%$ & 33 & $11 \%$ & 70 & $11 \%$ \\
\hline Energy & 1 & $0 \%$ & 4 & $1 \%$ & 5 & $1 \%$ \\
\hline Financial & 42 & $13 \%$ & 25 & $8 \%$ & 67 & $10 \%$ \\
\hline Industrial & 95 & $29 \%$ & 97 & $31 \%$ & 192 & $30 \%$ \\
\hline Technology & 52 & $16 \%$ & 59 & $19 \%$ & 111 & $17 \%$ \\
\hline Utilities & 1 & $0 \%$ & 5 & $2 \%$ & 6 & $1 \%$ \\
\hline Total & 331 & & 312 & & 643 & \\
\hline
\end{tabular}


(D)

\begin{tabular}{ccccccc}
\hline \multirow{2}{*}{ Industry Sector } & \multicolumn{3}{c}{ Numbers of IPOs } \\
\cline { 2 - 7 } & \multicolumn{2}{c}{ '03- 07} & \multicolumn{2}{c}{ '08-12 } & \multicolumn{2}{c}{ Total } \\
\hline Basic Materials & 20 & $9 \%$ & 9 & $9 \%$ & 29 & $9 \%$ \\
Communications & 19 & $8 \%$ & 7 & $7 \%$ & 26 & $8 \%$ \\
Consumer, Cyclical & 18 & $8 \%$ & 15 & $15 \%$ & 33 & $10 \%$ \\
Consumer, Non-cyclical & 40 & $17 \%$ & 17 & $17 \%$ & 57 & $17 \%$ \\
Energy & 7 & $3 \%$ & 9 & $9 \%$ & 16 & $5 \%$ \\
Financial & 16 & $7 \%$ & 7 & $7 \%$ & 23 & $7 \%$ \\
Industrial & 75 & $32 \%$ & 27 & $27 \%$ & 102 & $31 \%$ \\
Technology & 37 & $16 \%$ & 9 & $9 \%$ & 46 & $14 \%$ \\
Utilities & 0 & $0 \%$ & 0 & $0 \%$ & 0 & $0 \%$ \\
Total & 232 & & 100 & & 332 & \\
\hline
\end{tabular}

Table 2. Numbers of IPOs by exchange market. (A) Panel A Thailand; (B) Panel B China; (C) Panel C South Korea. (D) Panel D Malaysia.

(A)

\begin{tabular}{|c|c|c|c|c|c|c|}
\hline \multirow{3}{*}{$\begin{array}{l}\text { Exchange Market } \\
\text { Stock Exchange of Thailand }\end{array}$} & \multicolumn{6}{|c|}{ Numbers of IPOs } \\
\hline & \multicolumn{2}{|c|}{ '03-07 } & \multicolumn{2}{|c|}{ '08 - 12} & \multicolumn{2}{|c|}{ Total } \\
\hline & 107 & $70 \%$ & 29 & $43 \%$ & 136 & $62 \%$ \\
\hline Market for Alternative Investment & 46 & $30 \%$ & 38 & $57 \%$ & 84 & $38 \%$ \\
\hline Total & 153 & & 67 & & 220 & \\
\hline
\end{tabular}

(A)

\begin{tabular}{|c|c|c|c|c|c|c|}
\hline \multirow{3}{*}{$\begin{array}{c}\text { Exchange Market } \\
\text { Shanghai Stock Exchange }\end{array}$} & \multicolumn{6}{|c|}{ Numbers of IPOs } \\
\hline & \multicolumn{2}{|c|}{ '03- 07} & \multicolumn{2}{|c|}{ '08 - 12} & \multicolumn{2}{|c|}{ Total } \\
\hline & 148 & $42 \%$ & 97 & $10 \%$ & 245 & $19 \%$ \\
\hline Shenzhen Stock Exchange & 203 & $58 \%$ & 851 & $90 \%$ & 1,054 & $81 \%$ \\
\hline Total & 351 & & 948 & & 1,299 & \\
\hline
\end{tabular}

(C)

\begin{tabular}{|c|c|c|c|c|c|c|}
\hline \multirow{3}{*}{$\begin{array}{c}\text { Exchange Market } \\
\text { Korea Stock Exchange }\end{array}$} & \multicolumn{6}{|c|}{ Numbers of IPOs } \\
\hline & \multicolumn{2}{|c|}{ '03 - 07} & \multicolumn{2}{|c|}{ '08 - 12} & \multicolumn{2}{|c|}{ Total } \\
\hline & 81 & $24 \%$ & 74 & $24 \%$ & 155 & $24 \%$ \\
\hline KOSDAQ Exchange & 250 & $76 \%$ & 238 & $76 \%$ & 488 & $76 \%$ \\
\hline Total & 331 & & 312 & & 643 & \\
\hline
\end{tabular}

(D)

\begin{tabular}{|c|c|c|c|c|c|c|}
\hline \multirow{3}{*}{$\begin{array}{l}\text { Exchange Market } \\
\text { Bursa Malaysia }\end{array}$} & \multicolumn{6}{|c|}{ Numbers of IPOs } \\
\hline & \multicolumn{2}{|c|}{ '03 - 07} & \multicolumn{2}{|c|}{ '08 - 12} & \multicolumn{2}{|c|}{ Total } \\
\hline & 232 & $100 \%$ & 100 & $100 \%$ & 332 & $100 \%$ \\
\hline Total & 232 & & 100 & & 332 & \\
\hline
\end{tabular}


with medium to large market capital needs raise their funds. However, in the post-crisis period most IPOs were issued through the Market for Alternative Investment (MAI). Considering the differences of both exchanges, SET provides a platform for medium to large capitalisation enterprises, while MAI is suitable for small and medium size enterprises (SME). Firms listed on the SET exchange are generally more mature in their development, while the SMEs listed on the MAI exchange are firms seeking funds for growth.

\subsubsection{Analysis of IPOs in China}

Panel B of Table 1 shows that, in general, the number of IPOs issued in China increased substantially in the post-crisis period. A key factor behind this substantial increase in the number of Chinese IPOs during this period was the country's high rate of economic growth. For example, Chinese GDP increased by an annual rate of $9.6 \%$ and $10.4 \%$ in the years 2008 and 2010, respectively.

Another factor was that in 2007 the Chinese government introduced a new regulation that required local companies that were listed on the Hong Kong Stock Exchange to return to an exchange in mainland. The top three industry sectors in China before the crisis were industrial, consumer-cyclical, and consumer-non-cyclical $(30 \%, 16 \%$, and $16 \%$, respectively). After the crisis, there was no change in the top three positions, with the industrial sector expanding its share of the Chinese IPO market.

Panel B of Table 2 illustrates the number of IPOs issued on Chinese markets during the periods 2003-2007 and 2008-2012. While the Shanghai Stock Exchange experienced a decrease in the total number of IPOs being placed, the Shenzhen Stock Exchange experienced a considerable increase in IPO activity during the post-crisis period. In general, large market-capitalization companies are listed in Shanghai, whereas small and medium-capitalization companies are listed in Shenzhen.

\subsubsection{Analysis of IPOs in South Korea}

Panel C of Table 1 illustrates that the Korean IPO market was dominated by industrial and technology companies during the period 2003-2007. After 2007, the industrial sector still dominated IPO activity with a $31 \%$ market share followed by the technology sector with a $19 \%$ share of total IPOs. It appears that the financial crisis did not adversely affect the total number of IPOs coming to market in South Korea. The industrial and technology sectors in South Korea continued to perform well in the post-crisis period. In addition, South Korean companies managed to expand their exports to emerging markets, and Korea's GDP was supported by a recovery in domestic demand [69]. A key element in South Korea's rapid recovery from the financial crisis was the diversification within its export destinations.

Panel C of Table 2 indicates that the total number of IPOs being issued in South Korea was relatively unaffected by the financial crisis. Both of the exchanges in South Korea experienced only a slight decrease in the number of 
IPOs during the post-crisis period. The number of IPOs occurring on the KOSDAQ market is higher because this exchange is preferred by the vast majority of small and medium sized companies seeking to go public.

\subsubsection{Analysis of IPOs in Malaysia}

Panel D of Table 1 illustrates that the total number of IPOs on the Malaysian market was adversely affected by the financial crisis, as the total number declined by $57 \%$ between the pre-crisis and post-crisis periods. After the financial crisis, the Malaysian economy experienced a significant downturn i.e. $1.5 \%$ contraction in GDP during 2009. As investor sentiment is one of the most important factors affecting a company's decision to go public [5], it is no surprise that the downturn in the Malaysian economy delayed the IPOs of many private companies. Before the crisis, the main contributors of the Malaysian IPO market were industrial, consumer-cyclical, and technology sectors. After the crisis, the industrial sector still held a $27 \%$ market share, although the total number of IPOs in all sectors declined, apart from Energy.

Overall, the aforementioned tables of national IPO activity in the pre-crisis and post-crisis periods provide a record of how the financial crisis affected the total number of companies going public in each of the four Asian-Pacific countries. While the impact varied by country, the financial crisis reduced IPO activity in all countries apart from China. China was an exceptional as IPO activity during the period was supported by strong economic growth and a change in Chinese stock market regulations. Nonetheless, a common trend across the four countries is that IPOs were more frequently issued by companies from the industrial sectors of each economy.

\subsection{Short-Term Performance (Underpricing)}

Previous research on IPOs suggests that most public offerings are likely to be under-priced, and as a result, IPOs tend to generate significant positive returns during the first trading day [9] [31]. Next, this paper explores whether the level of IPO underpricing in Thailand, China, South Korea and Malaysia was affected by the global financial crisis.

\subsubsection{Underpricing in Thailand}

Panel A of Table 3 demonstrates that the average degree of IPO underpricing in Thailand during the pre-crisis 2003-2007 period was 19\%, which is significant at $1 \%$ level. This result is in line with previous research conducted by Chorruk, et al. [60] that examined the Thai market during 1997-2007 and found an average degree of underpricing of $17.6 \%$. Surprisingly, the average underpricing substantially increased to $44 \%$ after the crisis, which is also significant at $1 \%$ level. However, given the significant drop in IPO activity in Thai market post the 2007 financial crisis (see Table 1, Panel A) issuing Thai firms left on the table less US\$ than the pre-crisis period (US $\$ 0.1$ and 0.34 billion in the post-crisis and pre-crisis five years period, respectively). Ritter [31] mentions that riskier IPOs 
Table 3. Market-adjusted short-term returns of IPOs. (A) Panel A Thailand; (B) Panel B China; (C) Panel C South Korea; (D) Panel D Malaysia.

(A)

\begin{tabular}{cccc}
\hline & $2003-2007$ & $2008-2012$ & $2003-2012$ \\
\hline Mean & $0.190^{* * *}$ & $0.440^{* * *}$ & $0.266^{* * *}$ \\
$t$-statistic & 6.611 & 6.365 & 8.884 \\
Wealth Relative & 1.190 & 1.439 & 1.266 \\
Observations & 53 & 67 & 220 \\
\hline
\end{tabular}

$t$-statistic of the difference of the two sample mean market adjusted returns is $-3.956^{* * *}$.

(B)

\begin{tabular}{cccc}
\hline & $2003-2007$ & $2008-2012$ & $2003-2012$ \\
\hline Mean & $1.141^{\star * \star}$ & $0.415^{\star * \star}$ & $0.611^{\star * \star}$ \\
$t$-statistic & 22.059 & 25.350 & 29.913 \\
Wealth Relative & 2.140 & 1.416 & 1.612 \\
Observations & 351 & 948 & 1299 \\
\hline
\end{tabular}

$t$-statistic of the difference of the two sample mean market adjusted returns is $17.521^{\star * *}$.

(C)

\begin{tabular}{cccc}
\hline & $2003-2007$ & $2008-2012$ & $2003-2012$ \\
\hline Mean & $0.437^{\star * \star}$ & $0.279^{\star * *}$ & $0.360^{\star * *}$ \\
-statistic & 17.054 & 11.466 & 20.062 \\
Wealth Relative & 1.437 & 1.278 & 1.360 \\
Observations & 331 & 312 & 643 \\
\hline
\end{tabular}

$t$-statistic of the difference of the two sample mean market adjusted returns is $4.477^{\star * *}$.

(D)

\begin{tabular}{cccc}
\hline & $2003-2007$ & $2008-2012$ & $2003-2012$ \\
\hline Mean & $0.301^{* * *}$ & $0.113^{* * *}$ & $0.244^{* * *}$ \\
-statistic & 9.321 & 2.211 & 8.834 \\
Wealth Relative & 1.301 & 1.113 & 1.245 \\
Observations & 232 & 100 & 332 \\
\hline
\end{tabular}

$t$-statistic of the difference of the two sample mean market adjusted returns is $4.323^{* * *}$. Notes: the short-term performance of IPOs is measured using the percentage change of the closing price on the first trading day over the original issue price adjusted by the market return over the same period. ${ }^{*},{ }^{* *},{ }^{* *}$ denotes statistical significance at $10 \%, 5 \%$, and $1 \%$ level, respectively.

are likely to be more underpriced than less risky IPOs. According to asymmetric information theory, the uncertainty about the IPOs price is positively related to the degree of underpricing [3]. Not only the risk of economic downturn but also the political risk in Thailand had added more uncertainty to the Thai stock market. Thai political crisis has evolved since 2006 and got worsen in 2008 when the protestors decided to siege the international airport of Thailand. The changes of risk composition after the crisis push the IPO firms to provide more 
incentive for investors to invest in their firms in the time of high uncertainty.

Furthermore, the average level of IPO underpricing before and after the crisis in Thailand are significantly different from one another, at $1 \%$ level of significance. These results confirm that after the financial crisis in 2007, the underpricing of Thai IPOs significantly increased ${ }^{5}$. In general, Thai IPOs are more likely to be underpriced with a higher magnitude of underpricing after the crisis due to both external (the world economy slow down) and internal risk factors (the political unrest).

\subsubsection{Underpricing in China}

In contrast to the situation in Thailand, the magnitude of Chinese IPO underpricing declined dramatically after the financial crisis. This change in underpricing of Chinese IPOs is represented by the decline in the mean value of market-adjusted returns (MAAR) in Panel B of Table 3. Underpricing in China decreased significantly from $114.1 \%$ in the pre-crisis period to only $41.5 \%$ after the crisis. The $t$-statistics suggests that both mean values are significantly positive at the $1 \%$ level. Also, the $t$-statistic of the difference of the two sample means confirms that the two means are statistically different from each other.

The pre-crisis results of this study are in line with the results of previous studies of the Chinese IPO market. Chi, et al. [67] founda market-adjusted return during 1996-2000 of 129\%. Even though the severity of underpricing decreased in the post-crisis period ( $41.5 \%$ from $114.1 \%)$, it is still relatively high when compared to the underpricing present within most developed IPO markets. Given the significant increase in IPO activity in the Chinese market in the post-crisis period (see Table 1, Panel B), issuing Chinese firms left US $\$ 70$ billion on the table in the post-crisis period, an amount thatfar exceeded the total value left on the table during the pre-crisis period (US \$23 billion). The high level of IPO underpricing in China may be partly explained by the characteristics of Chinese stock market. Most Chinese investors are individual investors, who tend to lack investment knowledge and invest to earn speculative returns [70]. In addition while the demand for IPOs in China is high, the number of new shares available to investors is limited, due to the high proportion of shares held by governmental bodies. As a result, as Chinese investors attempt to buy shares of new IPO firms on the first trading day, the overall level of underpricing is increased.

In an effort to alleviate such structural market problems, during 2005 the Chinese government announced stock market reforms aimed to reduce the proportion of shares held by governmental bodies. This reform increased the availability of shares in certain Chinese IPOs, thereby reducing the overall level of underpricing in the Chinese stock markets.

${ }^{5}$ However, the average market-adjusted return of 44\% during 2008-2012 are in contrast to Chorruk, et al. [60] who suggests that IPOs in Thailand tend to be less under-priced than those of developed countries i.e. [53] documented average degrees of underpricing in the US, the UK, and Germany of $16.8 \%, 16.1 \%$ and $24.2 \%$, respectively. 


\subsubsection{Underpricing in South Korea}

Panel C of Table 3 suggests that similarly to the Chinese Market, underpricing of South Korean IPOs declined in the post-crisis period. The average market-adjusted return decreased from $43.7 \%$ to $27.9 \%$, at $1 \%$ level of significance. In addition, the $t$-test of the difference of the two-mean values was 4.48 indicating that the level of underpricing in the post-crisis period was significantly lower than in the pre-crisis period. In summary, IPOs in South Korea were generally underpriced in both time periods, although the amount left on the table increased from US $\$ 40$ and 64 billion during the pre-crisis and post-crisis periods, respectively.

\subsubsection{Underpricing in Malaysia}

Panel D of Table 3 illustrates the level of IPO underpricing in Malaysia. During 2003-2007, Malaysian IPOs were underpriced by an average of 30.1\%, at $1 \%$ level of significance. While these results are not in line with the earlier findings of Paudyal, et al. [58] who found average underpricing of 61.8\% during 1984-1995, they support the theoretical predictions that the privatisation of enterprises owned by the Malaysian state may contribute to the high level of IPO underpricing in the Malaysian market.

In the post-crisis period, Malaysian IPOs experienced similar trend in underpricing as those reported in China and South Korea. The average initial excess return of Malaysian IPOs decreased from $30.1 \%$ to $11.3 \%$, suggesting that underpricing was significantly lower(at the $1 \%$ level) in the post-crisis period ${ }^{6}$. Overall, as a consequence of IPO underpricing in the Malaysian market during 2003-2012, issuing Malaysian firms left US $\$ 2.3$ billion on the table. The overall results of our underpricing analysis in each of the four Asian-Pacific emerging markets supports the theoretical expectation of significant IPO underpricing in emerging markets during both the pre-crisis and post-crisis periods. Furthermore, it is commonly found that the level of IPO underpricing in the pre-crisis period differed from the post-crisis period which suggests that the financial crisis affected the pricing behaviour of IPOs in each country. However, it is important to note that the Thai IPO market showed an opposite trend to the other three countries. Thailand exhibited higher levels of underpricing because of severe political instability, while the other three countries faced lower underpricing due to reforms which reduced uncertainty. For example, IPO underpricing in China was influenced by regulatory reforms. However, the level of underpricing in each of the four emerging markets studied is relatively high when compared to the results of studies on IPOs in developed countries. The economic significance of the high level of IPO underpricing in the emerging markets of the Asian-Pacific region (given the high IPO activity) is evidenced by the fact that during 2003-2012 (before and after the financial crisis), issuing firms in the

${ }^{6}$ Demand for IPOs had dropped in Malaysia due to Global financial crisis (see Panel D of Table 1), which can be detected from the lower over-subscription ratio. The over-subscription ratio is partly related to the degree of underpricing. Lower over-subscription ratio usually results in lower initial return. 
four Asian-Pacific emerging markets left more than US $\$ 200$ billion on the table. The level of underpricing in these four Asian-Pacific emerging markets became more evident in the post-crisis period, given the increase of IPO activity in this period. In particular, issuing firms in these four Asian-Pacific emerging markets left on the table US $\$ 64$ and 136 billion in the pre-crisis and post-crisis five years period, respectively, which may affect negative the potentials for economic growth in the region. Although the results of short-term performance analysis provide valuable evidence about the extent of IPO underpricing in each country, it does not fully explain the overall performance of IPOs. As a result, next section analyses the long-term performance of IPOs in each of the four Asian-Pacific emerging markets in both the pre-crisis and post-crisis periods.

\subsection{Analysis of Long-Term Performance in Emerging IPO Markets}

Although the majority of prior studies provide evidence of widespread underpricing of IPOs, critics of such work argue that IPOs may not really be underpriced. For example, investment banks may correctly price an IPO but the offer price could be influenced by "noisyinvestors" who are overconfident (optimistic) about the potential growth of IPO companies [21]. Indeed, prior research suggests that IPO companies generally generate poor long-term returns for investors. However, this may not be the case for IPOs in emerging markets, as empirical evidence suggests that emerging markets provide outstanding long-term performance [55] [59] due to government intervention and rapid economic growth.

In order to extend our existing knowledge of long-term performance of IPOs in emerging markets, this section analyses the long-term performance of IPOs in the Asian-Pacific emerging markets of Thailand, China, South Korea, and Malaysia during the pre-crisis and post-crisis periods.

\subsubsection{Long-Term Performance of IPOs in Thailand}

Panel A of Table 4 summarises the long-term performance of Thai IPOs. CARs are calculated on a monthly basis from month 1 to 36 . The results indicate that the long-term performance of Thai IPOs appear to outperform the market index. During 2003-2007, the 36 month CAR is $7.5 \%$, at a $1 \%$ level of significance. The 36 month CAR achieved in the post-crisis period was $43.1 \%$, significantly higher than that achieved in the pre-crisis period, at a $1 \%$ level of significance ( $t$-statistic is 3.03).

Figure 1 illustrates the CAR results for Thai IPOs. Before the crisis, the CAR reached zero in month 16 and was negative up to month 27 . This poor long-term performance is similar to that found by Chorruk, et al. [60], who identified that the CAR of Thai IPOs declined to zero during month 24. Results of the post-crisis period are in contrast with the traditional pattern, as CAR remained positive from month 1 to 36 . The bullish trend in Thai stock market in the post-crisisperiod may be one of the factors that influence the long-term performance of IPOs to beat the benchmark. 
Table 4. Cumulative average benchmark-adjusted returns (CAR) for the pre-crisis period (2003-2007) and post-crisis period (2008-2013). (A) Panel A Thailand; (B) Panel B China; (C) Panel C South Korea; (D) Panel D Malaysia.

(A)

\begin{tabular}{ccccccccc}
\hline \multirow{2}{*}{ Month } & \multicolumn{9}{c}{$2003-2007$} & \multicolumn{2}{c}{$2008-2012$} \\
\cline { 2 - 9 } & CAR & StdDev & $t$-stat & Size & CAR & StdDev & $t$-stat & Size \\
\hline 12 & $0.031^{* * *}$ & 0.128 & 2.985 & 152 & $0.194^{* * *}$ & 0.142 & 9.578 & 49 \\
24 & $-0.046^{* * *}$ & 0.130 & -4.313 & 150 & $0.317^{* * *}$ & 0.101 & 19.586 & 39 \\
36 & $0.075^{* * *}$ & 0.186 & 4.880 & 147 & $0.431^{* * *}$ & 0.091 & 24.970 & 28
\end{tabular}

$t$-statistic of the difference of the two sample CARs over the 36 month period is $3.03^{* * *}$.

(B)

\begin{tabular}{ccccccccc}
\hline \multirow{2}{*}{ Month } & \multicolumn{3}{c}{$2003-2007$} & \multicolumn{5}{c}{$2008-2012$} \\
\cline { 2 - 8 } & CAR & StdDev & $t$-stat & Size & CAR & StdDev & $t$-stat & Size \\
\hline 12 & $-0.106^{* * *}$ & 0.125 & -15.883 & 351 & $-0.014^{* * *}$ & 0.102 & -3.817 & 798 \\
24 & $-0.052^{* * *}$ & 0.118 & -8.312 & 351 & -0.001 & 0.081 & -0.261 & 519 \\
36 & $0.050^{* * *}$ & 0.141 & 6.597 & 351 & $0.250^{* * *}$ & 0.250 & 34.942 & 171 \\
\hline
\end{tabular}

$t$-statistic of the difference of the two sample CARs over the 36 month period is $3.31^{* * *}$.

(C)

\begin{tabular}{ccccccccc}
\hline \multirow{2}{*}{ Month } & \multicolumn{3}{c}{$2003-2007$} & \multicolumn{5}{c}{$2008-2012$} \\
\cline { 2 - 8 } & CAR & StdDev & $t$-stat & Size & CAR & StdDev & $t$-stat & Size \\
\hline 12 & -0.009 & 0.156 & -1.094 & 331 & $0.097^{* * *}$ & 0.173 & 9.379 & 282 \\
24 & $0.091^{* * *}$ & 0.179 & 9.215 & 331 & $0.199^{* * *}$ & 0.147 & 18.295 & 204 \\
36 & $0.189^{* * *}$ & 0.136 & 25.165 & 331 & $0.505^{* * *}$ & 0.126 & 41.512 & 109 \\
\hline
\end{tabular}

$t$-statistic of the difference of the two sample CARs over the 36 month period is $1.77^{\star}$.

(D)

\begin{tabular}{cccccccccc}
\hline \multirow{3}{*}{ Month } & \multicolumn{3}{c}{$2003-2007$} & \multicolumn{5}{c}{$2008-2012$} \\
\cline { 2 - 9 } & CAR & StdDev & $t$-stat & Size & CAR & StdDev & $t$-stat & Size \\
\hline 12 & $-0.036^{* * *}$ & 0.128 & -4.291 & 231 & $-0.115^{* * *}$ & 0.111 & -9.670 & 87 \\
24 & $-0.185^{\star * *}$ & 0.147 & -19.215 & 231 & $-0.203^{* * *}$ & 0.088 & -18.064 & 61 \\
36 & $-0.258^{* * *}$ & 0.162 & -24.248 & 231 & $-0.309^{* * *}$ & 0.140 & -13.057 & 35 \\
\hline
\end{tabular}

$t$-statistic of the difference of the two sample CARs over the 36 month period is 0.74 . Notes: Cumulative average benchmark-adjusted abnormal return (CAR) over 12, 24 and 36 month period is the sum of the monthly average market-adjusted abnormal returns during the relevant period. ${ }^{*},{ }^{* *},{ }^{* *}$ denotes statistical significance at $10 \%, 5 \%$, and $1 \%$ level, respectively.

\subsubsection{Long-Term Performance of IPOs in China}

CARs over the 36 months period shown in Panel B of Table 4 illustrate that Chinese IPOs outperformed the market during both 2003-2007 and 2008-2012 periods, $5 \%$ and $25 \%$, respectively. In addition, it is evident that IPO CARs for the 36 months post-crisis period are significantly higher than those of the pre-crisis period, at $1 \%$ level ( $t$-statistic is 3.31 ). 


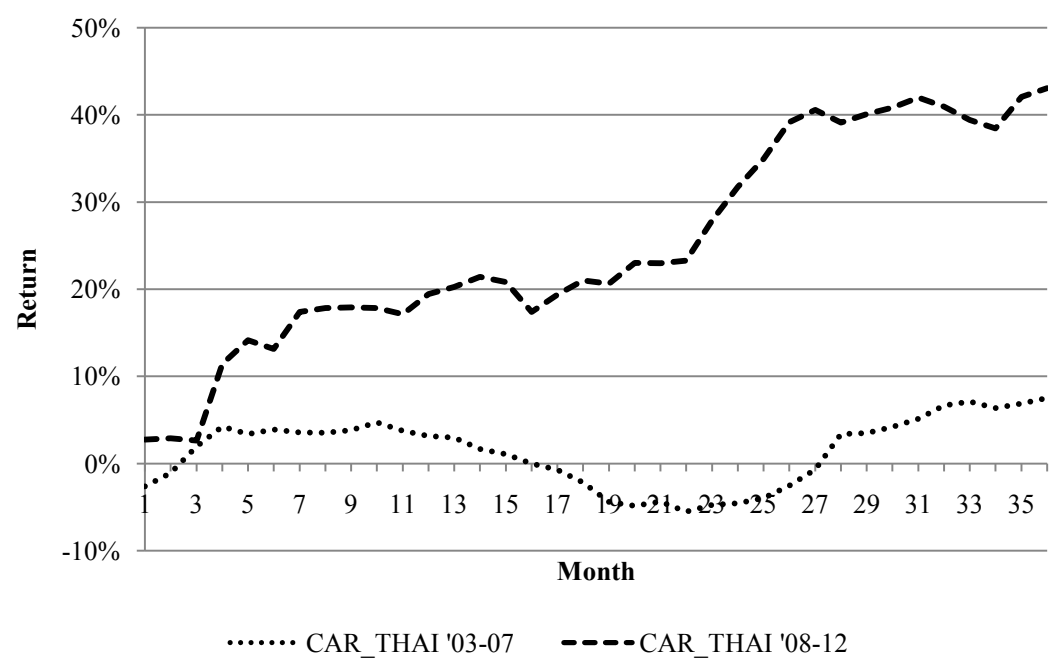

Figure 1. Thai IPOs-Cumulative average benchmark-adjusted returns for pre-crisis (2003-2007) and post-crisis (2008-2013) periods.

Chen, et al. [71] investigated IPO CARs in China over the period 1996 to 2005 and found that CARs over 24 and 36 months period are $2.4 \%$ and $-0.1 \%$, respectively. They suggest that the long-term IPO CAR is not likely to outperform the market. Similarly, Figure 2, which provides a detailed picture of the Chinese IPOs performance in the pre and post-crisis period, illustrates that the CARs of Chinese IPOs during most of the pre-crisis period underperformed the market. On the contrary the CARs of the post-crisis period appear to over perform the market especially after the 24 months post-IPO period.

\subsubsection{Long-Term Performance of IPOs in South Korea}

Panel C of Table 4 documents the long-term performance of South Korean IPOs. The long-term performance results for South Korean IPOs are interesting as they differ from the results obtained from the other emerging markets under investigation. In particular CARs over the 36 months period during the pre-crisis and post-crisis periods are both significantly positive, $18.9 \%$ and $50.5 \%$, respectively, at $1 \%$ level of significance. These findings are in line with the earlier work of Kim, et al. [55], who found that Korean IPOs were likely to generate outstanding long-term performance.

Figure 3 illustrates that Korean IPOs are likely to outperform the market in the long-term. However, the $t$-test for the difference of the two sample mean values (see Panel C of Table 4) suggests that there is a significantly statistical difference (only at $10 \%$ level) between the CARs before and after the financial crisis. A possible explanation for the increased (post-crisis) long-term performance of Korean IPOs is that their returns were influenced by the improved performance of the Korean Stock Market, whose index increased from 1100 to 2000 points during the period 2009-2012.

\subsubsection{Long-Term Performance of IPOs in Malaysia}

Malaysia is the only country where long-term IPO performance resulted in high 


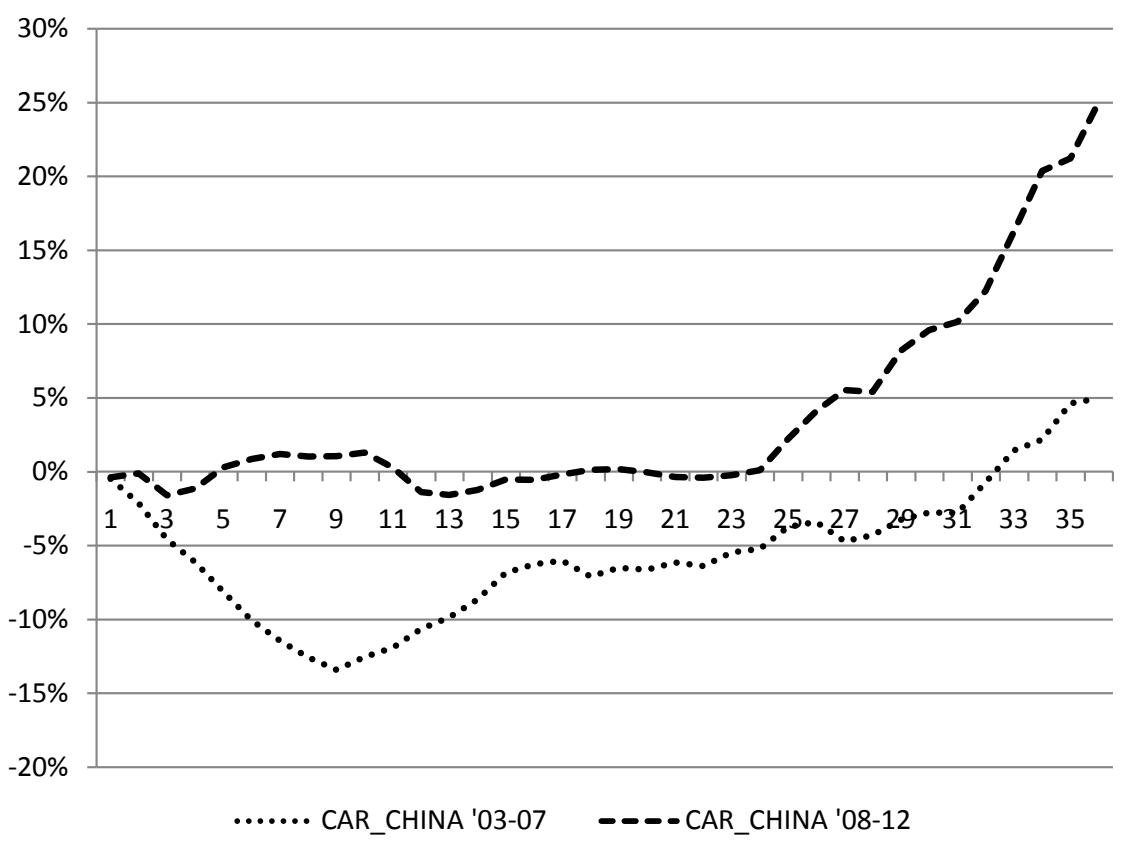

Figure 2. Chinese IPOs-Cumulative average benchmark-adjusted returns by month for pre-crisis (2003-2007) and post-crisis (2008-2013) periods.

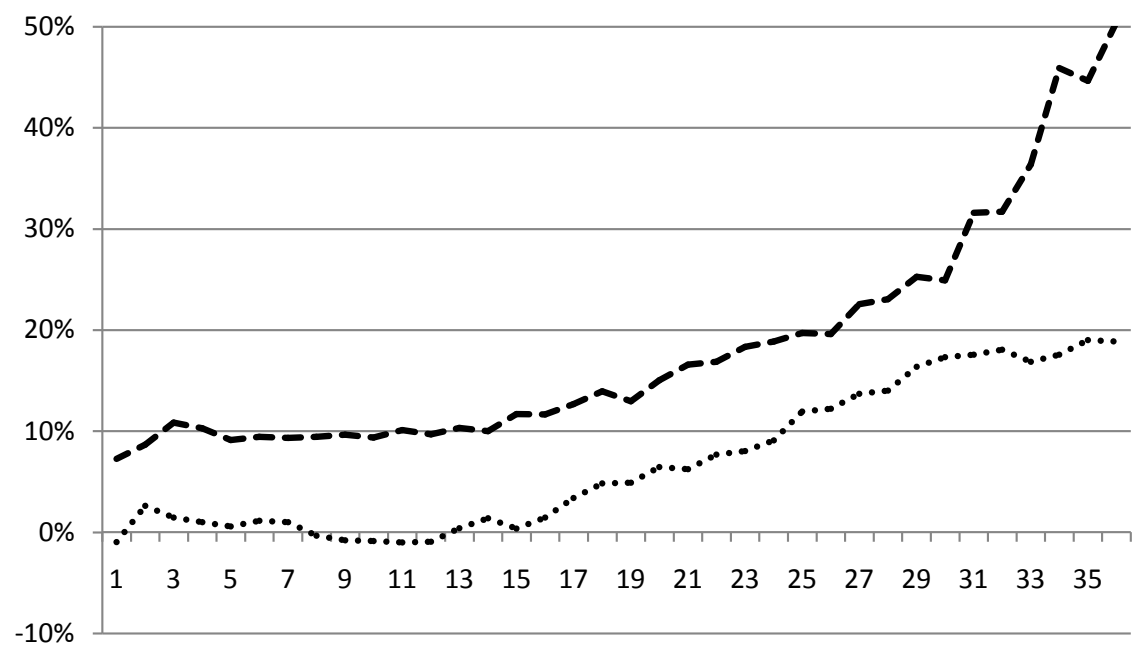

\section{CAR_KOREA '03-07 - - CAR_KOREA '08-12}

Figure 3. South Korean IPOS-Cumulative average benchmark-adjusted returns for pre-crisis (2003-2007) and post-crisis (2008-2013) periods.

negative returns. Panel D of Table 4 illustrates that IPO CARs over the 36 month period were $-25.8 \%$ and $-30.9 \%$ in the pre-crisis and post crisis periods, respectively. Previous research on the Malaysian IPO market suggests that Malaysian IPOs did not out-perform or under-perform the market [58]. On the other hand, Jelic, et al. [59] suggest that Malaysian IPOs tend to outperform the market in the long-term. The results of the present study appear to differ due to the calendar period being analysed and the methodology used. For example, 


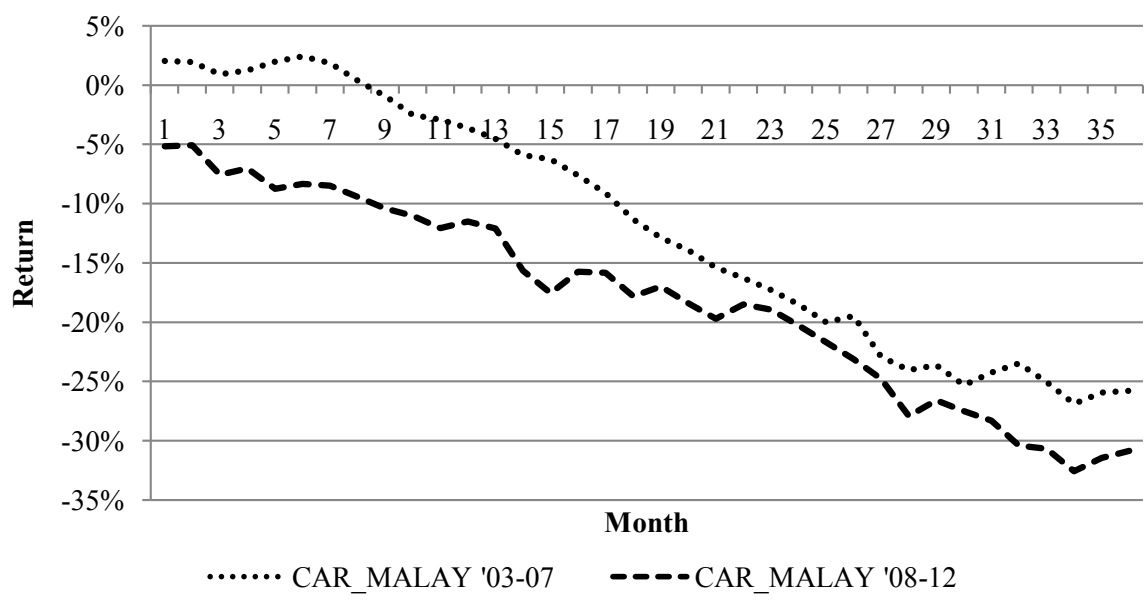

Figure 4. Malaysia-Cumulative average benchmark-adjusted returns for pre-crisis (2003-2007) and post-crisis (2008-2013) periods.

Paudyal, et al. [58] applied daily market-adjusted compounded returns.

Figure 4 provides clear evidence that Malaysian IPOs underperformed the market in both periods.

\section{Conclusions}

This study investigated the effects of the 2007 global financial crisis on the relative short-term and long-term performance of IPOs in the Asian-Pacific emerging markets of Thailand, China, South Korea, and Malaysia. The results of this study suggest that the short and long-term performance of IPOs in each of the four emerging markets were significantly affected by the 2007 financial crisis. However, the extent of this impact was inconsistent across the four markets.

While IPO underpricing increased in Thailand partly as a result of increased political uncertainty, the level of underpricing actually decreased in China, South Korea, and Malaysia. Between the pre-crisis and post crisis periods, IPO underpricing in Thailand increased from $19 \%$ to $44 \%$. In contrast, underpricing in Chinese, South Korean and Malaysian IPO markets declined from $114 \%$ to $41.5 \%, 43.7 \%$ to $27.9 \%$, and $30.1 \%$ to $11.3 \%$, respectively. Even though underpricing in emerging markets has been reduced due to regulatory reforms [72] [73], it is still high compared to developed markets. This may be due to government ownership [74], owner dispersion [75], and ex-ante uncertainty [38] [71].

In terms of the long-term performance of IPOs in the post-crisis period, IPOs in Thailand, China, and South Korea all outperformed the benchmark in the 36 month period after each IPOs was placed. In contrast, the long-term performance of Malaysian IPOs was poor. During the post-crisis period of 2008-2012, IPOs in South Korea generated the highest performance with a CAR of 50.5\% during the 36 months period after IPO placement. The post-crisis long-term CAR performance results for Thailand, China and Malaysia were 43.1\%, 25\% and $-30.9 \%$, respectively.

The long-term performance results for each of the four emerging markets are 
interesting, as they also contradict the results and observations from IPOs studies in developed markets. While, most IPOs in developed markets appear to underperform the market in the long-term, the results of this study suggest that IPOs in emerging markets outperformed the market in the long-run, especially in the post-crisis period.

The policy implications of this study are very important for financial regulators and corporations (firms) seeking for new sources of finance through capital markets. More specifically, the economic significance of the high level of IPO underpricing in the Asian-Pacific emerging markets during 2003-2012 period (before and after the financial crisis) is evident by the US $\$ 200$ billion left on the table by issuing firms. Given the increase of IPO activity in the Asian-Pacific emerging markets in the post-crisis period, the significance of the economic implications of IPO underpricing in the emerging markets (in the Asian-pacific region) becomes more evident. In particular, issuing firms in these four Asian-Pacific emerging markets left on the table US $\$ 64$ and 136 billion in the pre-crisis and post-crisis five years period, respectively, which may affect negative the potentials for economic growth in the region.

In this research study the analysis of the IPO performance is limited only to four (emerging) countries. In addition, the research on the IPO performance is conducted separately for each country to provide more specific information for each country's IPO performance. Future research on the IPO performance of the Asian-pacific emerging markets may be conducted on a pooled basis.

The inconsistency in the comparative short and long-term performance of IPOs in emerging and developed markets is a potential area for future research. In addition, it would be interesting to investigate the specific factors that affect IPO performance in emerging markets. For instance, Warther [76] found a high correlation between security returns and fund flows, and Richards [77] investigated the impact of foreign investors in emerging markets. As a result, the 2007 financial crisis may have diverted international capital flows towards emerging markets, thereby increasing overall IPO performance in these regions.

\section{Acknowledgements}

The authors would like to thank the editor and the three anonymous reviewers for their helpful comments on a previous version of this paper.

\section{Conflicts of Interest}

The authors declare no conflicts of interest regarding the publication of this paper.

\section{References}

[1] Loughran, T. and Ritter, J. (2002) Why Don't Issuers Get Upset about Leaving Money on the Table in IPOs? The Review of Financial Studies, 15, 413-444.

https://doi.org/10.1093/rfs/15.2.413 
[2] Ibbotson, R. and Jaffe, J. (1975) "Hot Issue" Markets. The Journal of Finance, 30, 1027-1042.

[3] Beatty, R. and Ritter, J. (1986) Investment Banking, Reputation, and the Underpricing of Initial Public Offerings. Journal of Financial Economics, 15, 213-232. https://doi.org/10.1016/0304-405X(86)90055-3

[4] Loughran, T. and Ritter, J. (2004) Why Has IPO Underpricing Changed Over Time? Financial Management, 33, 5-37.

[5] Lowry, M. (2003) Why Does IPO Volume Fluctuate So Much? Journal of Financial Economics, 67, 3-40. https://doi.org/10.1016/S0304-405X(02)00230-1

[6] Kim, M. and Ritter, J. (1999) Valuing IPOs. Journal of Financial Economics, 53, 409-437. https://doi.org/10.1016/S0304-405X(99)00027-6

[7] Yong, O. (2007) A Review of IPO Research in Asia: What's Next? Pacific-Basin Finance Journal, 15, 253-275. https://doi.org/10.1016/j.pacfin.2006.09.001

[8] Ljungqvist, A. (2007) IPO Underpricing. In: Eckbo, B.E., Ed., Handbook of Corporate Finance: Empirical Corporate Finance Volume 1, North-Holland, New Hampshire, USA.

[9] Ibbotson, R. (1975) Price Performance of Common Stock New Issues. Journal of Financial Economics, 2, 235-272. https://doi.org/10.1016/0304-405X(75)90015-X

[10] Logue, D. (1973) On the Pricing of Unseasoned Equity Issues: 1965-1969. The Journal of Financial and Quantitative Analysis, 8, 91-103. https://doi.org/10.2307/2329751

[11] Rock, K. (1986) Why New Issues Are Underpriced. Journal of Financial Economics, 15, 187-212. https://doi.org/10.1016/0304-405X(86)90054-1

[12] Baron, D. (1982) A Model of the Demand for Investment Banking Advising and Distribution Services for New Issues. The Journal of Finance, 37, 955-976. https://doi.org/10.1111/j.1540-6261.1982.tb03591.x

[13] Cooney, J., Singh, A., Carter, R. and Dark, F. (2001) IPO Initial Returns and Underwriter Reputation: Has the Inverse Relation Flipped in the 1990s. Working Paper, University of Kentucky.

[14] Brennan, M. and Franks, J. (1997) Underpricing, Ownership and Control in Initial Public Offerings of Equity Securities in the UK. Journal of Financial Economics, 45, 391-413. https://doi.org/10.1016/S0304-405X(97)00022-6

[15] Booth, J. and Chua, L. (1996) Ownership Dispersion, Costly Information, and IPO Underpricing. Journal of Financial Economics, 41, 291-310. https://doi.org/10.1016/0304-405X(95)00862-9

[16] Tinic, S. (1988) Anatomy of Initial Public Offerings of Common Stock. The Journal of Finance, 43, 789-822. https://doi.org/10.1111/j.1540-6261.1988.tb02606.x

[17] Drake, P. and Vetsuypens, M. (1993) IPO Underpricing and Insurance against Legal Liability. Financial Management, 22, 64-73. https://doi.org/10.2307/3665966

[18] Alexander, J. (1993) Lawsuit Avoidance Theory of Why Initial Public Offerings Are Underpriced. The UCLA Law Review, 41, 17-74.

[19] Dandapani, K., Dossani, R., Prakash, A. and Reside, M. (1992) Personal Taxes and the Underpricing of Initial Public Offerings. Managerial and Decision Economics, 13, 279-286. https://doi.org/10.1002/mde.4090130402

[20] Rydqvist, K. (1997) IPO Underpricing as Tax-Efficient Compensation. Journal of Banking \& Finance, 21, 295-313. https://doi.org/10.1016/S0378-4266(96)00043-X

[21] Purnanandam, A. and Swaminathan, B. (2004) Are IPOs Really Underpriced? The 
Review of Financial Studies, 17, 811-848. https://doi.org/10.1093/rfs/hhg055

[22] Daniel, K., Hirshleifer, D. and Teoh, S. (2002) Investor Psychology in Capital Markets: Evidence and Policy Implications. Journal of Monetary Economics, 49, 139-209. https://doi.org/10.1016/S0304-3932(01)00091-5

[23] Bloomfield, R., Libby, R. and Nelson, M. (2000) Underreactions, Overreactions and Moderated Confidence. Journal of Financial Markets, 3, 113-137. https://doi.org/10.1016/S1386-4181(00)00003-3

[24] Shiller, R., Fischer, S. and Friedman, B. (1984) Stock Prices and Social Dynamics. Brookings Papers on Economic Activity, 2, 457-510. https://doi.org/10.2307/2534436

[25] Aggarwal, R. and Rivoli, P. (1990) Fads in the Initial Public Offering Market? Financial Management, 19, 45-57. https://doi.org/10.2307/3665609

[26] Malkiel, B. and Fama, E. (1970) Efficient Capital Markets: A Review of Theory and Empirical Work. The Journal of Finance, 25, 383-417. https://doi.org/10.1111/j.1540-6261.1970.tb00518.x

[27] Kleidon, A. (1986) Bias in Small Sample Tests of Stock Price Rationality. Journal of Business, 59, 237-261. https://doi.org/10.1086/296327

[28] Marsh, T. and Merton, R. (1986) Dividend Variability and Variance Bounds Tests for the Rationality of Stock Market Prices. The American Economic Review, 76, 483-498.

[29] Lee, P., Taylor, S. and Walter, T. (1996) Australian IPO Pricing in the Short and Long Run. Journal of Banking \& Finance, 20, 1189-1210.

https://doi.org/10.1016/0378-4266(95)00053-4

[30] McDonald, J. and Fisher, A. (1972) New-Issue Stock Price Behavior. The Journal of Finance, 27, 97-102. https://doi.org/10.1111/j.1540-6261.1972.tb00624.x

[31] Ritter, J. (1984) The "Hot Issue" Market of 1980. The Journal of Business, 15, 215-240. https://doi.org/10.1086/296260

[32] Jog, V. and Riding, A. (1987) Underpricing in Canadian IPOs. Financial Analysts Journal, 43, 48-55. https://doi.org/10.2469/faj.v43.n6.48

[33] Kooli, M. and Suret, J. (2004) The Aftermarket Performance of Initial Public Offerings in Canada. Journal of Multinational Financial Management, 14, 47-66. https://doi.org/10.1016/S1042-444X(03)00038-0

[34] Ljungqvist, A. (1997) Pricing Initial Public Offerings: Further Evidence from Germany. European Economic Review, 41, 1309-1320. https://doi.org/10.1016/S0014-2921(96)00035-9

[35] Dawson, S. (1987) Secondary Stock Market Performance of Initial Public Offers, Hong Kong, Singapore, and Malaysia: 1978-1984. Journal of Business Finance \& Accounting, 14, 65-76. https://doi.org/10.1111/j.1468-5957.1987.tb00529.x

[36] Mok, H. and Hui, Y. (1998) Underpricing and Aftermarket Performance of IPOs in Shanghai, China. Pacific-Basin Finance Journal, 6, 453-474.

https://doi.org/10.1016/S0927-538X(98)00023-7

[37] Su, D. and Fleisher, B. (1999) An Empirical Investigation of Underpricing in Chinese IPOs. Pacific-Basin Finance Journal, 7, 173-202. https://doi.org/10.1016/S0927-538X(99)00005-0

[38] Su, D. and Fleisher, B. (1998) Risk, Return and Regulation in Chinese Stock Markets. Journal of Economics and Business, 50, 239-256.

https://doi.org/10.1016/S0148-6195(98)00002-2 
[39] Chan, K., Wang, J. and Wei, K.C. (2004) Underpricing and Long-Term Performance of IPOs in China. Journal of Corporate Finance, 10, 409-430. https://doi.org/10.1016/S0929-1199(03)00023-3

[40] Perera, W. and Kulendran, N. (2012) New Evidence of Short-Run Underpricing in Australian IPOs. Working Paper.

[41] Boulton, T., Smart, S. and Zutter, C. (2011) Earnings Quality and International IPO Underpricing. The Accounting Review, 86, 483-505. https://doi.org/10.2308/accr.00000018

[42] Bernile, G., Kumar, A. and Sulaeman, J. (2012) Home away from Home: Relevance and Local Investors. AFA 2012 Chicago Meetings Paper.

[43] Nielsson, U. and Wójcik, D. (2016) Proximity and IPO Underpricing. Journal of Corporate Finance, 38, 92-105. https://doi.org/10.1016/j.jcorpfin.2016.03.012

[44] Gounopoulos, D., Kallias, A., Kallias, K. and Tzeremes, P. (2017) Political Money Contributions of US IPOs. Journal of Corporate Finance, 43, 19-38. https://doi.org/10.1016/j.jcorpfin.2016.12.011

[45] Gounopoulos, D. and Pham, H. (2018) Specialist CEOs and IPO Survival. Journal of Corporate Finance, 48, 217-243. https://doi.org/10.1016/j.jcorpfin.2017.10.012

[46] Ritter, J. (1991) The Long-Run Performance of Initial Public Offerings. The Journal of Finance, 46, 3-27. https://doi.org/10.1111/j.1540-6261.1991.tb03743.x

[47] Jaskiewicz, P., González, V., Menéndez, S. and Schiereck, D. (2005) Long-Run IPO Performance Analysis of German and Spanish Family-Owned Businesses. Family Business Review, 18, 179-202. https://doi.org/10.1111/j.1741-6248.2005.00041.x

[48] Carter, R., Dark, F. and Singh, A. (1998) Underwriter Reputation, Initial Returns, and the Long-Run Performance of IPO Stocks. The Journal of Finance, 53, 285-311. https://doi.org/10.1111/0022-1082.104624

[49] Su, C. and Bangassa, K. (2011) The Impact of Underwriter Reputation on Initial Returns and Long-Run Performance of Chinese IPOs. Journal of International Financial Markets, Institutions and Money, 21, 760-791. https://doi.org/10.1016/j.intfin.2011.06.002

[50] Dong, M., Michel, J. and Pandes, J. (2011) Underwriter Quality and Long-Run IPO Performance. Financial Management, 40, 219-251. https://doi.org/10.1111/j.1755-053X.2010.01140.x

[51] Davies, P. (2012) Emerging Markets Take Bigger Share of IPOs. The Financial Times, 28 June.

[52] Bekaert, G. (1995) Market Integration and Investment Barriers in Emerging Equity Markets. The World Bank Economic Review, 9, 75-107. https://doi.org/10.1093/wber/9.1.75

[53] Loughran, T., Ritter, J. and Rydqvist, K. (1994) Initial Public Offerings: International Insights. Pacific-Basin Finance Journal, 2, 165-199. https://doi.org/10.1016/0927-538X(94)90016-7

[54] Kim, J., Krinsky, I. and Lee, J. (1993) Motives for Going Public and Underpricing: New Findings from Korea. Journal of Business Finance \& Accounting, 20, 195-211. https://doi.org/10.1111/j.1468-5957.1993.tb00659.x

[55] Kim, J.-B., Krinsky, I. and Lee, J. (1995) The Role of Financial Variables in the Pricing of Korean Initial Public Offerings. Pacific-Basin Finance Journal, 3, 449-464. https://doi.org/10.1016/0927-538X(95)00017-F

[56] Yong, O. and Isa, Z. (2003) Initial Performance of New Issues of Shares in Malaysia. 
Applied Economics, 35, 919-930. https://doi.org/10.1080/0003684022000020869

[57] Menyah, K. and Paudyal, K. (1996) Share Issue Privatisations: The UK Experience. London Guildhall University, Centre for International Capital Markets, London.

[58] Paudyal, K., Saadouni, B. and Briston, R.J. (1998) Privatisation Initial Public Offerings in Malaysia: Initial Premium and Long-Term Performance. Pacific-Basin Finance Journal, 6, 427-451. https://doi.org/10.1016/S0927-538X(98)00018-3

[59] Jelic, R., Saadouni, B. and Briston, R. (2001) Performance of Malaysian IPOs: Underwriters Reputation and Management Earnings Forecasts. Pacific-Basin Finance Journal, 9, 457-486. https://doi.org/10.1016/S0927-538X(01)00013-0

[60] Chorruk, J. and Worthington, A. (2010) New Evidence on the Pricing and Performance of Initial Public Offerings in Thailand, 1997-2008. Emerging Market Review, 11, 285-299. https://doi.org/10.1016/j.ememar.2010.04.001

[61] Wethayavivorn, K. and Koo-Smith, Y. (1991) Initial Public Offerings in Thailand, 1988-1989: Price and Return Patterns. Pacific-Basin Capital Market Research, North-Holland, Amsterdam, 379-394.

[62] Allen, D., Morkel-Kingsbury, N. and Piboonthanakiat, W. (1999) The Long-Run Performance of Initial Public Offerings in Thailand. Applied Financial Economics, 9, 215-232. https://doi.org/10.1080/096031099332294

[63] Vithessonthi, C. (2008) The Long-Run Performance of Initial Public Offerings: New Evidence from Thailand. The Business Review, 10, 315-321.

[64] McWilliams, A. and Seigel, D. (1997) Event Study in Management Research: Theoretical and Empirical Issues. Academy of Management Journal, 40, 626-657.

[65] MacKinlay, A. (1997) Event Studies in Economics and Finance. Journal of Economic Literature, 35, 13-39.

[66] Rosa, R.S., Velayuthen, G. and Walter, T. (2003) The Sharemarket Performance of Australian Venture Capital Backed and Non-Venture Capital Backed IPOs. Pacific-Basin Finance Journal, 11, 197-218. https://doi.org/10.1016/S0927-538X(02)00114-2

[67] Chi, J. and Padgett, C. (2005) Short-Run Underpricing and Its Characteristics in Chinese Initial Public Offering (IPO) Markets. Research in International Business and Finance, 19, 71-93. https://doi.org/10.1016/j.ribaf.2004.10.004

[68] Brav, A. and Gompers, P. (1997) Myth or Reality? The Long-Run Underperformance of Initial Public Offerings: Evidence from Venture and Nonventure Capital-Backed Companies. The Journal of Finance, 52, 1791-1821. https://doi.org/10.1111/j.1540-6261.1997.tb02742.x

[69] Leon-Manriquez, J. (2010) The Global Crisis of 2008 in South Korea and Mexico: The Role of Internal Market and Regional Trade. Working Paper, Metropolitan Autonomous University.

[70] Xia, N., Junyan, S. and Pe, G. (2013) Empirical Study on Initial Public Offering (IPO) Underpricing and Long-Run Performance: Evidence from China's A-Share Market. African Journal of Business Management, 7, 852-861.

[71] Chen, G., Firth, M. and Kim, J. (2004) IPO Underpricing in China's New Stock Markets. Journal of Multinational Financial Management, 14, 283-302. https://doi.org/10.1016/j.mulfin.2003.07.007

[72] Ekkayokkaya, M. and Pengniti, T. (2012) Governance Reform and IPO Underpricing. Journal of Corporate Finance, 18, 238-253. https://doi.org/10.1016/j.jcorpfin.2011.12.007

[73] Chang, K., Kim, Y., Kim, Y. and Thornton Jr., J. (2012) Unintended Regulatory 
Consequences: Evidence from the Korean IPOs. Pacific-Basin Finance Journal, 20, 292-309. https://doi.org/10.1016/j.pacfin.2011.10.002

[74] Liao, J. and Young, M. (2012) The Impact of Residual Government Ownership in Privatized Firms: New Evidence from China. Emerging Markets Review, 13, 338-351. https://doi.org/10.1016/j.ememar.2012.02.004

[75] Hussin, W.N.W. (2005) The Effects of Owners' Participation and Lockup on IPO Underpricing in Malaysia. Asian Academy of Management Journal, 10, 19-36.

[76] Warther, V. (1995) Aggregate Mutual Fund Flows and Security Returns. Journal of Financial Economics, 39, 209-235. https://doi.org/10.1016/0304-405X(95)00827-2

[77] Richards, A. (2005) Big Fish in Small Ponds: The Trading Behavior and Price Impact of Foreign Investors in Asian Emerging Equity Markets. Journal of Financial and Quantitative Analysis, 40, 1-27. https://doi.org/10.1017/S0022109000001721 